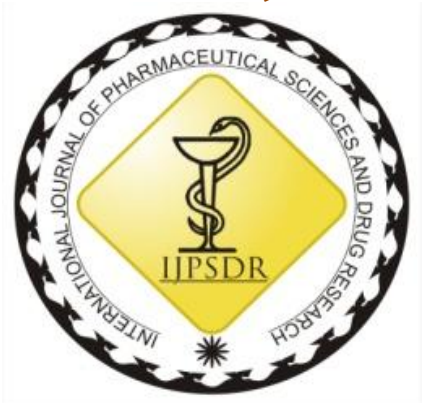

ISSN: 0975-248X

Research Article CODEN (USA): IJPSPP

(c) BY-NC-SA

\title{
Development of Stability Indicating RP-HPLC Method for Simultaneous Estimation of Amlodipine and Olmesartan in Pure and Pharmaceutical Dosage Form
}

\author{
Dhiraj Kumar1 $^{*}$, Susanta Kumar Panda², Sudhir Kumar Sahoo \\ ${ }^{1}$ Guru Nanak Institutions Technical Campus - School of Pharmacy, Ibrahimpattnam, Hyderabad-501506, \\ Telangana, India \\ ${ }^{2}$ Royal College of Pharmacy and Health Sciences, Berhampur, Gnajam, Odisha, India
}

Copyright (c) 2018 Dhiraj Kumar et al. This is an open access article distributed under the terms of the Creative Commons AttributionNonCommercial-ShareAlike 4.0 International License which allows others to remix, tweak, and build upon the work non-commercially, as long as the author is credited and the new creations are licensed under the identical terms.

\begin{abstract}
A precise, accurate, economical and simple stability indicating RP-HPLC method was developed for the estimation of Amlodipine (AML) and Olmesartan (OLM) in bulk and pharmaceutical dosage form. Method was performed on a octadecyl silane column with dimensions $4.6 \times 250 \mathrm{~mm}$ having particle size 5 micron. The mobile phase used in the method is TEA Buffer ( $\mathrm{pH} 3.0$ ) and acetonitrile in proportion of 25:75 respectively. The flow rate was maintained at $1.0 \mathrm{ml} / \mathrm{min}$ and effluent was monitored at $258 \mathrm{~nm}$. The drug was subjected to acid and alkali hydrolysis, oxidation, photolysis and heat as stress conditions. The method was validated for specificity, linearity, precision, accuracy, robustness and system suitability. The retention times were observed at $2.39 \mathrm{~min}$ and $3.33 \mathrm{~min}$ for AML and OLM respectively. The standard curve was found linear over a range of $05-35 \mu \mathrm{g} / \mathrm{ml}$ for AML and OLM. Similarly an average correlation coefficient was also obtained at 0.999 for AML and OLM. The limit of quantitation (LOQ) of this method was $2 \mu \mathrm{g} / \mathrm{ml}$ for Amlodipine and Olmesartan. The absolute recovery was $100 \%$ for Amlodipine and 100.3 for Olmesartan. Degradation products produced as a result of stress studies did not interfere with the detection of AML and OLM and the assay can thus be considered stability-indicating.
\end{abstract}

Keywords: Amlodipine, Olmesartan, RP-HPLC, TEA Buffer: Acetonitrile, Validation.

*Corresponding author: Mr. Dhiraj Kumar

Address: Guru Nanak Institutions Technical Campus - School of Pharmacy, Ibrahimpattnam, Hyderabad-501506, Telangana, India Tel.: +91-9441285823

E-mail $\bowtie$ : dhirajkumar5707@gmail.com

Relevant conflicts of interest/financial disclosures: The authors declare that the research was conducted in the absence of any commercial or financial relationships that could be construed as a potential conflict of interest.

Received: 17 July, 2018; Revised: 28 August, 2018; Accepted: 30 August, 2018; Published: 23 September, 2018

\section{INTRODUCTION}

Amlodipine is a long-acting 1,4-dihydropyridine calcium channel blocker. It acts primarily on vascular smooth muscle cells by stabilizing voltage-gated L-type calcium channels in their inactive conformation. By inhibiting the influx of calcium in smooth muscle cells, amlodipine prevents calcium-dependent myocyte contraction and vasoconstriction. Amlodipine 
decreases arterial smooth muscle contractility and subsequent vasoconstriction by inhibiting the influx of calcium ions through L-type calcium channels. Calcium ions entering the cell through these channels bind to calmodulin. Calcium-bound calmodulin then binds to and activates myosin light chain kinase (MLCK). Activated MLCK catalyzes the phosphorylation of the regulatory light chain subunit of myosin, a key step in muscle contraction. ${ }^{[1]}$

Olmesartan is an antihypertensive agent, which belongs to the class of medications called angiotensin II receptor blockers. Olmesartan is an ARB that selectively inhibits the binding of angiotensin II to AT1, which is found in many tissues such as vascular smooth muscle and the adrenal glands. This effectively inhibits the AT1-mediated vasoconstrictive and aldosterone-secreting effects of angiotensin II and results in a decrease in vascular resistance and blood pressure.

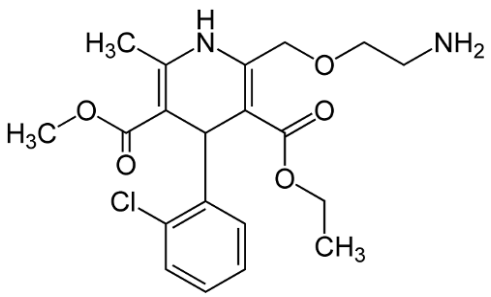

Fig. 1: Amlodipine

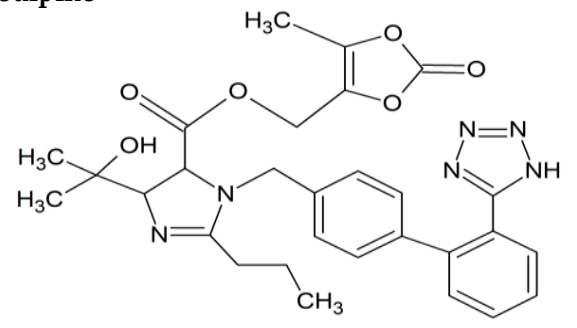

Fig. 2: Olmesartan

Literature survey shows that very few works on stability-indicating RP-HPLC method has been reported so far for the simultaneous estimation of both the drugs using mobile phase TEA buffer and Acetonitrile in proportion of 25:75. Some of the reported methods are for OLM using UV-Spectroscopic method [1-4], RP-HPLC method [5-6], for combination of three drugs AML, OLM and HTZ using RP-HPLC method [7-9], for AML using RP HPLC method. [10] Very few methods have been reported so far for simultaneous estimation of both the drugs AML and OLM. ${ }^{[11-16]}$ The objective of this work was to develop a new rapid, novel, and economical RP-HPLC method which can be used as a stability-indicating assay for combination drug product of AML and OLM.

\section{MATERIALS AND METHODS}

\section{Drugs}

Pure pharmaceutical sample of AML and OLM was obtained from Yucca Pharma. Olmark tablet (Intas Pharmaceuticals Ltd) containing amlodipine besylate (5 $\mathrm{mg}$ ) and olmesartan medoxomil $(20 \mathrm{mg})$ were procured from the local drug market.

\section{Chemicals}

Sodium dihydrogen phosphate (AR Grade), 85\% Orthophosphoric acid (AR Grade), Acetonitrile (HPLC Grade), Hydrochloric Acid (AR Grade), Triethyl-Amine (AR Grade), Sodium Hydroxide (AR Grade) were purchased from $S d$ fine-Chem limited.

\section{Instrument}

Liquid chromatographic system from Waters alliance 2695 with Waters UV detector equipped with Empower software was used.

\section{Preparation of mobile phase}

Mobile phase was prepared by dissolving Buffer of $\mathrm{pH}$ 3 in Acetonitrile in the ratio of 25:75. The Mobile phase was filtered through $0.45 \mu \mathrm{m}$ membrane filter and degassed by ultrasonic bath.

\section{Preparation of TEA buffer ( $\mathrm{pH} 3)$}

The buffer solution was prepared by dissolving $1.5 \mathrm{ml}$ of Triethyl amine dissolved in $250 \mathrm{ml}$ of HPLC Water. The $\mathrm{pH}$ was adjusted at 3.00 with ortho phosphoric acid.

\section{Diluent preparation}

The Mobile phase was used as the diluent.

\section{Stock solutions and standards}

A stock solution of drugs were prepared by transferring accurately weighed $25 \mathrm{mg}$ of AML and OLM in two separate $25 \mathrm{ml}$ volumetric flask and dissolved in $15 \mathrm{ml}$ of mobile phase. The solutions were sonicated and the volumes were made up to mark with mobile phase to get concentration of $1000 \mu \mathrm{g} / \mathrm{ml}$ of AML and OLM.

\section{Preparation of Sub Stock Solution}

$1 \mathrm{ml}$ was pippeted from Amlodipine stock solution and $4 \mathrm{ml}$ from Olmesartan stock solution. The solutions were transferred in $100 \mathrm{ml}$ volumetric flask separately. The volume was made up to the mark with mobile phase to get concentration of $10 \mu \mathrm{g} / \mathrm{ml}$ and $40 \mu \mathrm{g} / \mathrm{ml}$ solution of AML and OLM respectively.

\section{Preparation of sample solution}

Accurately weighed ten tablets were taken and crushed in mortar and pestle. $100 \mathrm{mg}$ equivalent weight of powdered drug containing OLM and AML were transferred into a $100 \mathrm{~mL}$ volumetric flask and volume was made up to the mark with the solvent. Further $2 \mathrm{ml}$ pipetted out from stock solution and transferred into a $50 \mathrm{ml}$ volumetric flask and diluted up to the mark with diluent.

\section{Stability Study}

Tablet powder equivalent to the weight of one tablet was transferred to a $250 \mathrm{ml}$ round bottomed flask and treated under acidic, alkaline, oxidizing, thermal and photolytic stress conditions. When degradation was complete, the solution were left to equilibrate to room temperature and diluted with diluents to furnish solutions of concentration equivalent to $40 \mu \mathrm{g} / \mathrm{ml}$ OLM and $10 \mu \mathrm{g} / \mathrm{ml}$ AML. The specific conditions are described below. In acidic degradation drug was heated under reflux with $1 \mathrm{M}$ hydrochloric acid for 30 min at $80^{\circ} \mathrm{C}$ and the drug was treated with $0.1 \mathrm{~N} \mathrm{NaOH}$ at room temperature for $2 \mathrm{~h}$ in alkaline degradation. 
Then resulting solution was neutralized. The drug was treated with $2 \% \mathrm{v} / \mathrm{v} \mathrm{H}_{2} \mathrm{O}_{2}$ at room temperature for 2 hour in oxidative degradation. Thermal degradation was performed by exposing the solid drug to dry heat in a convection oven at $70^{\circ} \mathrm{C}$ for $72 \mathrm{~h}$ and photolytic degradation was performed by exposing the drug to sunlight for $72 \mathrm{~h}$.

\section{Apparatus and Chromatographic conditions}

Quantitative HPLC was performed on Waters HPLC system with UV detector. Empower software is used along with a stainless steel column $4.6 \times 150 \mathrm{~mm}$, packed with Octa decyl silane bonded to porous silica (C18) with particle size 5 micron. To develop a suitable and robust HPLC method for the determination of OLM and AML, different mobile phases containing TEA buffer and Acetonitrile were used in different compositions like (30:70, 40:60, 50:50, 70:30, 80:20) at different flow rates $(0.5,0.75,1.0,1.2,1.5 \mathrm{ml} / \mathrm{min})$. The mobile phase TEA buffer and Acetonitrile with a flow rate of $1.0 \mathrm{ml} / \mathrm{min}$ gave peaks of good resolution and were eluted at retention times around $2.39 \mathrm{~min}, 3.33$ min with symmetric peak shape. The detection is performed at the wavelength $258 \mathrm{~nm}$.

Running the standard solution of Amlodipine

$1 \mathrm{ml}$ of stock solution (1000 ppm) was pipetted out into a $100 \mathrm{ml}$ volumetric flask. The volume was made up to the mark with mobile phase. The solution was filtered through the $0.45 \mu \mathrm{m}$ membrane filter and degassed under ultrasonic bath prior to use. The solution was injected into the HPLC system. The chromatogram obtained is shown in figure 3 .

Running the standard solution of Olmesartan

$4 \mathrm{ml}$ of stock solution was pipetted into a $100 \mathrm{ml}$ volumetric flask. The volume was made up to the mark with mobile phase. The solution was filtered through the $0.45 \mu \mathrm{m}$ membrane filter and degassed under ultrasonic bath prior to use. The solution was injected into the HPLC system. The chromatogram obtained is shown in figure 4.

Running the standard solution of Amlodipine and Olmesartan

$1 \mathrm{ml}$ of AML stock solution and $4 \mathrm{ml}$ OLM stock solution was pipetted into a $100 \mathrm{ml}$ volumetric flask. The volume was made up to the mark with mobile phase. The solution was filtered through the $0.45 \mu \mathrm{m}$ membrane filter and degassed under ultrasonic bath prior to use. The solution was injected into the HPLC system. The chromatogram obtained is shown in figure 5.

\section{Method development and optimization}

The main target of the chromatographic method is to get the separation of closely eluting drugs Amlodipine and Olmesartan, The drugs were co-eluted by using different stationary phases like C18, C8 with varying lengths and different mobile phases containing buffers like phosphate, sulphate and acetate with different $\mathrm{pH}$ (2-7) and using organic modifiers like acetonitrile, methanol and ethanol in the mobile phase. $\mathrm{pH}$ of the buffer has played a significant role in achieving the separation between drugs.

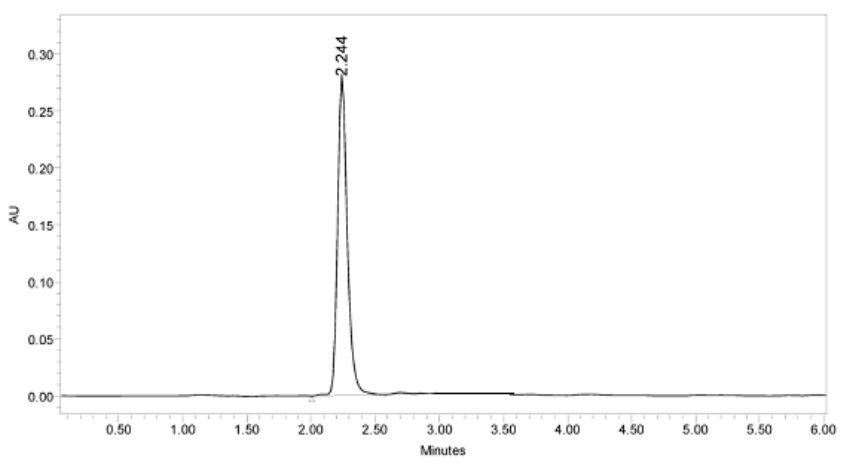

Fig. 3: Chromatogram of Amlodipine (Rt $2.395 \mathrm{~min}$ )

\begin{tabular}{cccccccc}
\hline $\begin{array}{c}\text { S. } \\
\mathbf{N}\end{array}$ & $\begin{array}{c}\text { Peak } \\
\text { Name }\end{array}$ & $\mathbf{R}_{\mathbf{t}}$ & Area & $\begin{array}{c}\text { Heig } \\
\text { ht }\end{array}$ & $\begin{array}{c}\text { USP } \\
\text { Resoluti } \\
\text { on }\end{array}$ & $\begin{array}{c}\text { USP } \\
\text { Taili } \\
\text { ng }\end{array}$ & $\begin{array}{c}\text { USP } \\
\text { plat } \\
\text { e }\end{array}$ \\
\hline 1 & $\begin{array}{c}\text { Amlodip } \\
\text { ine }\end{array}$ & $\begin{array}{c}2.31 \\
6\end{array}$ & $\begin{array}{c}12321 \\
42\end{array}$ & $\begin{array}{c}19412 \\
3\end{array}$ & 3.6 & 1.2 & 4651 \\
\hline
\end{tabular}

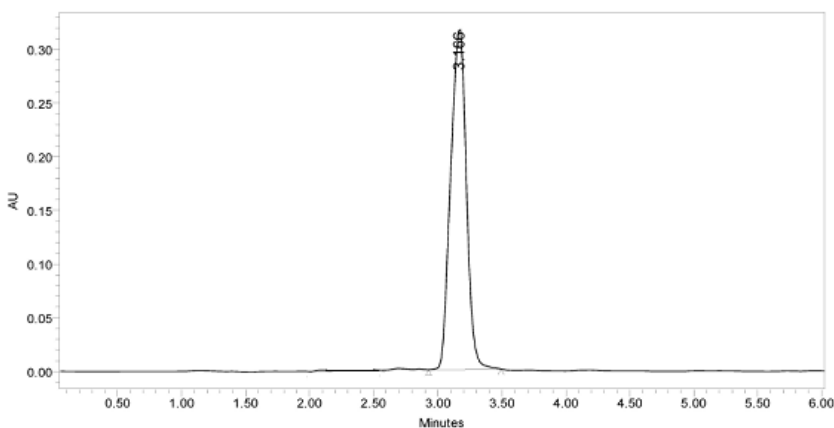

Fig. 4: Chromatogram of Olmesartan (Rt $3.339 \mathrm{~min})$

\begin{tabular}{cccccccc}
\hline $\begin{array}{c}\text { S. } \\
\mathbf{N} \\
\mathbf{0}\end{array}$ & $\begin{array}{c}\text { Peak } \\
\text { Name }\end{array}$ & $\mathbf{R}_{\mathbf{t}}$ & Area & $\begin{array}{c}\text { Hei } \\
\text { ght }\end{array}$ & $\begin{array}{c}\text { USP } \\
\text { Resoluti } \\
\text { on }\end{array}$ & $\begin{array}{c}\text { USP } \\
\text { Tailin } \\
\text { g }\end{array}$ & $\begin{array}{c}\text { USP plate } \\
\text { count }\end{array}$ \\
\hline 1 & $\begin{array}{c}\text { Olmes } \\
\text { artan }\end{array}$ & $\begin{array}{c}3.3 \\
04\end{array}$ & $\begin{array}{c}1491 \\
465\end{array}$ & $\begin{array}{ll}176 \\
582\end{array}$ & 5.6 & 1.5 & 3982 \\
\hline
\end{tabular}

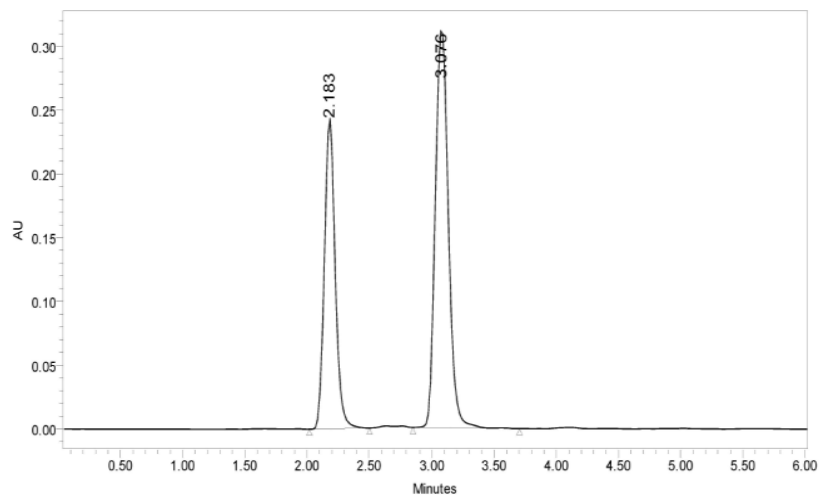

Fig. 5: Chromatogram of Amlodipine (Rt $2.395 \mathrm{~min}$ ) and Olmesartan (Rt $3.339 \mathrm{~min})$.

\begin{tabular}{cccccccc}
\hline $\begin{array}{c}\text { S. } \\
\text { No }\end{array}$ & $\begin{array}{c}\text { Peak } \\
\text { Name }\end{array}$ & $\mathbf{R}_{\mathbf{t}}$ & Area & $\begin{array}{c}\text { Heig } \\
\text { ht }\end{array}$ & $\begin{array}{c}\text { USP } \\
\text { Resolut }\end{array}$ & $\begin{array}{c}\text { USP } \\
\text { Taili }\end{array}$ & $\begin{array}{c}\text { USP plate } \\
\text { count }\end{array}$ \\
\hline 1 & Amlodi & 2.3 & 124238 & 1973 & & 1.1 & 4741 \\
& pine & 95 & 8 & 32 & & & \\
2 & $\begin{array}{c}\text { Olmesar } \\
\text { tan }\end{array}$ & 3.3 & $\begin{array}{c}149484 \\
8\end{array}$ & $\begin{array}{c}1778 \\
25\end{array}$ & 5.2 & 1.2 & 3793 \\
\hline
\end{tabular}


The chromatographic separation was achieved on a stainless steel column $(4.6 \times 250 \mathrm{~mm})$ column packed with Octa decyl silane bonded to porous silica (C18) with particle size 5 micron, by using solutions TEA Buffer and Acetonitrile in the ratio of (25:75), $\mathrm{pH}$ adjusted to 3 using ortho phosphoric acid. The flow rate of the mobile phase was maintained at $1.0 \mathrm{ml} / \mathrm{min}$. At $25^{\circ} \mathrm{C}$ of column temperature, the peak shape of AML AND OLM was found symmetrical with mobile phase 60:40 ratio. In the optimized conditions AML AND OLM were well separated with a good resolution and the typical retention times of AML AND OLM were about $2.3 \mathrm{~min}$ and $3.3 \mathrm{~min}$, respectively. The system suitability results are given in table 1 and the developed LC method was validated. [16]

\begin{tabular}{|c|c|}
\hline Instrument used & $\begin{array}{l}\text { Waters HPLC with auto sampler and UV } \\
\text { detector }\end{array}$ \\
\hline Temperature & Ambient \\
\hline Column & $\begin{array}{c}\text { Symmetry C18 }\left(\begin{array}{c}(4.6 \mathrm{~mm} \times 150 \mathrm{~mm}, 5 \mu \mathrm{m}, \text { Make: } \\
\text { Waters })\end{array}\right.\end{array}$ \\
\hline Buffer & $\begin{array}{l}1.5 \mathrm{ml} \text { of Triethyl amine dissolve in } 250 \mathrm{ml} \text { of } \\
\text { HPLC water. Adjust pH } 3.00 \text { with } \\
\text { orthophosphoric acid. }\end{array}$ \\
\hline $\mathrm{pH}$ & 3 \\
\hline Mobile phase & $\begin{array}{l}\text { TEA Buffer ( } \mathrm{pH}-3.00) \text {, Acetonitrile in } \\
\text { proportion of } 25: 75\end{array}$ \\
\hline Flow rate & $1 \mathrm{ml}$ per min \\
\hline Wavelength & $258 \mathrm{~nm}$ \\
\hline Injection volume & $20 \mu \mathrm{l}$ \\
\hline Run time & $6 \min$ \\
\hline
\end{tabular}

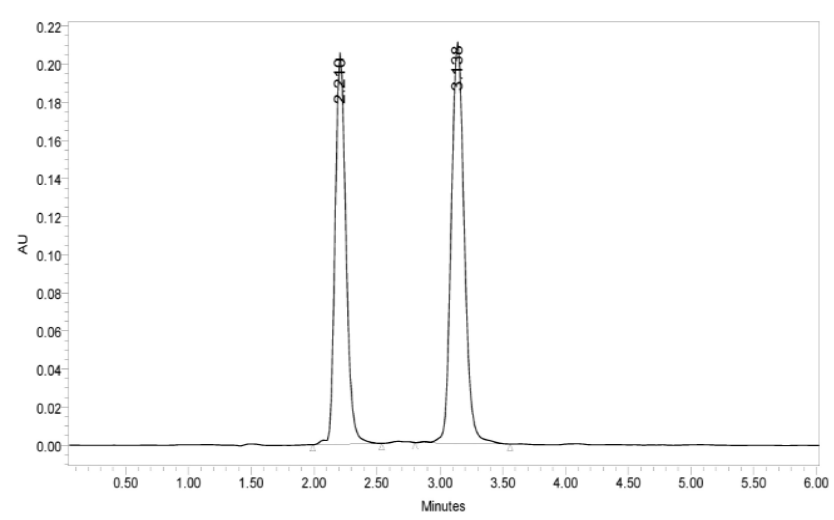

Fig. 6: Chromatogram showing degradation for Amlodipine and Olmesartan in $0.1 \mathrm{~N} \mathrm{HCl}$

\begin{tabular}{ccccccc}
\hline $\begin{array}{c}\text { S. } \\
\text { No }\end{array}$ & Peak Name & $\mathbf{R}_{\mathbf{t}}$ & Area & Height & $\begin{array}{c}\text { USP } \\
\text { Tailing }\end{array}$ & $\begin{array}{c}\text { USP } \\
\text { plate } \\
\text { count }\end{array}$ \\
\hline 1 & Amlodipine & 2.210 & 1113179 & 198754 & 1.2 & 4854 \\
2 & Olmesartan & 3.138 & 1339383 & 176582 & 1.3 & 3872 \\
\hline
\end{tabular}

\section{Stability Studies}

\section{Acid Hydrolysis}

An accurately weighed $25 \mathrm{mg}$ of pure drugs AML and $100 \mathrm{mg}$ of OLM were transferred to a clean \& dry $25 \mathrm{ml}$ volumetric flask separately. To which $0.1 \mathrm{~N}$ Hydrochloric acid was added \& made up to the mark \& kept for 24 hours. From both drug solutions $0.5 \mathrm{ml}$ was taken and transferred in to a $50 \mathrm{ml}$ volumetric flask \& made up to the mark with mobile phase and then injected into the HPLC system against a blank of $\mathrm{HCl}$ (after all optimized conditions).

\section{Basic Hydrolysis}

An accurately weighed $25 \mathrm{mg}$ of pure drugs AML and $100 \mathrm{mg}$ of OLM were transferred to a clean \& dry $25 \mathrm{ml}$ volumetric flask separately. To which $0.5 \mathrm{~N}$ Sodium hydroxide was added \& make up to the mark \& kept for 24 hours, From both drug solution $0.5 \mathrm{ml}$ was taken in to a $50 \mathrm{ml}$ volumetric flask \& make up to the mark with mobile phase, then injected into the HPLC system against a blank of $\mathrm{NaOH}$ (after all optimized conditions).

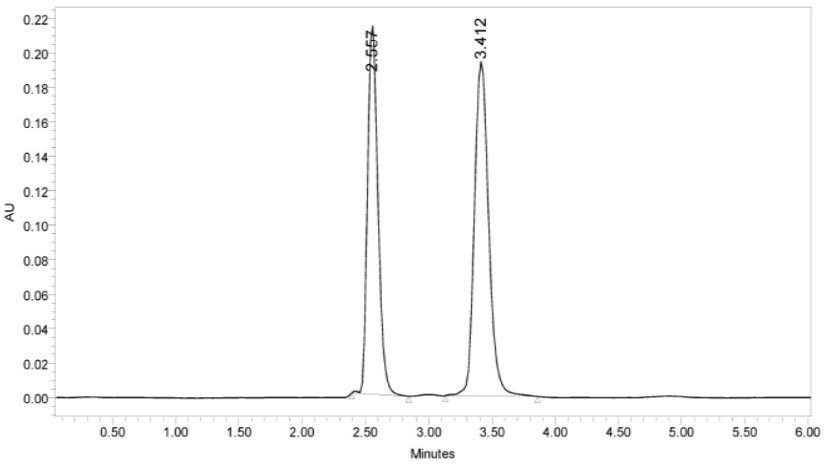

Fig. 7: Chromatogram showing degradation related impurity in $\mathbf{0 . 1}$ $\mathrm{N} \mathrm{NaOH}$

\begin{tabular}{ccccccc}
\hline $\begin{array}{c}\text { S. } \\
\text { No. }\end{array}$ & Peak Name & $\mathbf{R}_{\mathbf{t}}$ & Area & Height & $\begin{array}{c}\text { USP } \\
\text { Tailing }\end{array}$ & $\begin{array}{c}\text { USP } \\
\text { plate } \\
\text { count }\end{array}$ \\
\hline 1 & Amlodipine & 2.557 & 1153184 & 198574 & 1.0 & 4658 \\
2 & Olmesartan & 3.412 & 1387517 & 187452 & 1.1 & 3694 \\
\hline
\end{tabular}

\section{Dry Heat Degradation}

An accurately weighed $25 \mathrm{mg}$ of pure drugs AML and $100 \mathrm{mg}$ of OLM were transferred in to a $25 \mathrm{ml}$ volumetric flask, volume was made up to the mark with mobile phase \& maintained at $50^{\circ} \mathrm{C}$ for 24 hours. From both drug solutions $0.5 \mathrm{ml}$ was taken in to a $50 \mathrm{ml}$ volumetric flask \& make up to the mark with mobile phase. Further it is injected into the HPLC system against a blank of mobile phase.

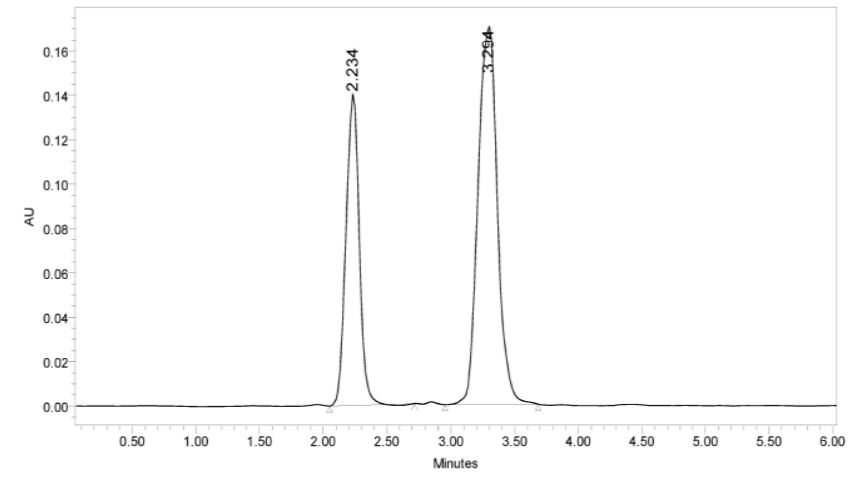

Fig. 8: Chromatogram showing thermal degradation studies

\begin{tabular}{ccccccc}
\hline $\begin{array}{c}\text { S. } \\
\text { No. }\end{array}$ & Peak Name & $\mathbf{R}_{\mathbf{t}}$ & Area & Height & $\begin{array}{c}\text { USP } \\
\text { Tailing }\end{array}$ & $\begin{array}{c}\text { USP } \\
\text { plate } \\
\text { count }\end{array}$ \\
\hline 1 & Amlodipine & 2.234 & 1181262 & 198698 & 1.2 & 4821 \\
2 & Olmesartan & 3.294 & 1432363 & 169587 & 1.4 & 3365 \\
\hline
\end{tabular}




\section{Photolytic Degradation}

Approximately $25 \mathrm{mg}$ of pure drugs AML and $100 \mathrm{mg}$ of OLM were taken in a clean \& dry Petri dish. It was kept in a UV cabinet at $254 \mathrm{~nm}$ wavelength for 24 hours without interruption. Accurately weighed $1 \mathrm{mg}$ of AML and $4 \mathrm{mg}$ of OLM the UV exposed drug was transferred to a clean \& dry $100 \mathrm{ml}$ volumetric flask. First the UV exposed drug was dissolved in methanol \& make up to the mark.Then injected into the HPLC system against a blank of mobile phase (after all optimized conditions).

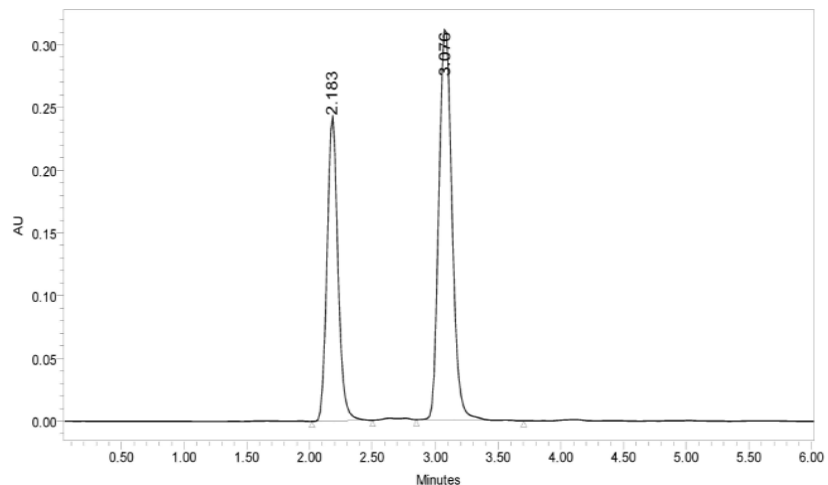

Fig. 9: Chromatogram is showing photolytic degradation.

\begin{tabular}{ccccccc}
\hline $\begin{array}{c}\text { S. } \\
\text { No. }\end{array}$ & Peak Name & $\mathbf{R}_{\mathbf{t}}$ & Area & Height & $\begin{array}{c}\text { USP } \\
\text { Tailing }\end{array}$ & $\begin{array}{c}\text { USP } \\
\text { plate } \\
\text { count }\end{array}$ \\
\hline 1 & Amlodipine & 2.183 & 1212073 & 186954 & 1.0 & 4857 \\
2 & Olmesartan & 3.076 & 1458373 & 169587 & 1.2 & 3635 \\
\hline
\end{tabular}

Oxidation with $3 \% \mathrm{H}_{2} \mathrm{O}_{2}$

Accurately weighed $1 \mathrm{mg}$ of AML and $4 \mathrm{mg}$ of OLM of pure drugs were taken in a clean \& dry $100 \mathrm{ml}$. volumetric flask. $30 \mathrm{ml}$. of $3 \% \quad \mathrm{H}_{2} \mathrm{O}_{2}$ and a little methanol was added to it to make it soluble \& then kept as such in dark for 24 hours. Final volume was made up to $100 \mathrm{ml}$. using water to prepare $10 \mathrm{ppm}$ and $40 \mathrm{ppm}$ of AML and OLM solution respectively. The above sample was injected into the HPLC system.

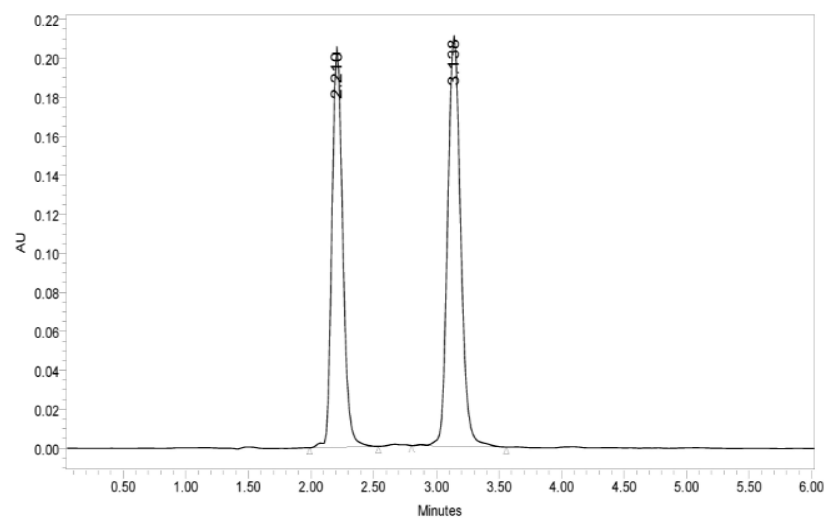

Fig. 10: Chromatogram shows oxidative degradation.

\begin{tabular}{ccccccc}
\hline $\begin{array}{c}\text { S. } \\
\text { No. }\end{array}$ & Peak Name & $\mathbf{R}_{\mathbf{t}}$ & Area & Height & $\begin{array}{c}\text { USP } \\
\text { Tailing }\end{array}$ & $\begin{array}{c}\text { USP } \\
\text { plate } \\
\text { count }\end{array}$ \\
\hline 1 & Amlodipine & 2.210 & 1120882 & 198596 & 1.2 & 4635 \\
2 & lmesartan & 3.138 & 1348651 & 177854 & 1.5 & 3458 \\
\hline
\end{tabular}

\section{RESULTS AND DISCUSSION}

\section{Results of forced degradation studies}

The results of the stress studies indicated the specificity of the method that has been developed. Amlodipine and Olmesartan were stable in photolytic, thermal and basic stress conditions. The result of forced degradation studies are given in the following table 2.

Results of method validation

Linearity

Linear calibration plot for assay method was obtained over the calibration ranges tested, i.e. $1-3 \mu \mathrm{g} / \mathrm{ml}$ for Amlodipine and $2 \mu \mathrm{g} / \mathrm{ml}$ to $30 \mu \mathrm{g} / \mathrm{ml}$ for Olmesartan and the correlation coefficient obtained was greater than 0.999. The results show that an excellent correlation existed between the peak area and concentration of the analyte which is given in table 3 and 4.

Table 2: Results of forced degradation studies of Amlodipine and Olmesartan API

\begin{tabular}{ccccc}
\hline $\begin{array}{c}\text { Stress } \\
\text { condition }\end{array}$ & $\begin{array}{c}\text { Time } \\
\text { (h) }\end{array}$ & $\begin{array}{c}\text { Assay of } \\
\text { degraded } \\
\text { products }\end{array}$ & $\begin{array}{c}\text { Assay of } \\
\text { active } \\
\text { substance }\end{array}$ & $\begin{array}{c}\text { Mass } \\
\text { Balance } \\
\text { (\%) }\end{array}$ \\
\hline $\begin{array}{c}\text { Acid } \\
\text { Hydrolysis } \\
(0.1 \mathrm{M} \mathrm{HCl})\end{array}$ & 24 & 10.4 & 89.6 & 100 \\
$\begin{array}{c}\text { Basic } \\
\text { Hydrolysis }\end{array}$ & 24 & 7.18 & 92.82 & 100 \\
$\begin{array}{c}\text { (0.I M NaOH) } \\
\text { Thermal }\end{array}$ & & & & \\
$\begin{array}{c}\text { Degradation } \\
\left(50^{\circ} \mathrm{C}\right)\end{array}$ & 24 & 4.92 & 95.08 & 100 \\
$\begin{array}{c}\text { UV }(254 \mathrm{~nm}) \\
3 \% \text { Hydrogen } \\
\text { peroxide }\end{array}$ & 24 & 2.44 & 97.56 & 100 \\
\hline
\end{tabular}

Table 3: Linearity results for Amlodipine Concentration of AML in ppm

\begin{tabular}{cc} 
of $\mathbf{A M L}$ in $\mathbf{p p m}$ & Peak area \\
\hline 0 & 0 \\
5 & 224748 \\
10 & 475848 \\
15 & 692648 \\
20 & 944621 \\
25 & 1180741 \\
30 & 1390935 \\
35 & 1598929 \\
\hline
\end{tabular}

\begin{tabular}{cc} 
Table 4: Linearity results for Olmersartan \\
\hline Concentration of OLM in ppm & Peak area \\
\hline 0 & 0 \\
5 & 1234613 \\
10 & 2472924 \\
15 & 3570426 \\
20 & 4853049 \\
25 & 6053925 \\
30 & 6990601 \\
35 & 7817235 \\
\hline
\end{tabular}

\section{Intermediate precision/ruggedness}

To evaluate the intermediate precision (also known as Ruggedness) of the method, Precision was performed on different day by using different make column of same dimensions.

Recovery and accuracy

The percentage recovery of AML and OLM in bulk drugs samples was ranged from 99.4-99.6\% which 
indicates that the method was accurate which is given in table 7.

\begin{tabular}{|c|c|c|c|c|c|}
\hline $\begin{array}{l}\text { S. } \\
\text { No. }\end{array}$ & Peak name & $\mathbf{R t}$ & $\begin{array}{c}\text { Area } \\
\left(\mu V^{*} \text { sec }\right)\end{array}$ & $\begin{array}{c}\text { USP Plate } \\
\text { Count }\end{array}$ & $\begin{array}{c}\text { USP } \\
\text { Tailing }\end{array}$ \\
\hline 1 & Amlodipine & 2.234 & 1010585 & 1.0 & 3802 \\
\hline 2 & Amlodipine & 2.261 & 1011075 & 1.1 & 3546 \\
\hline 3 & Amlodipine & 2.183 & 1011924 & 1.4 & 4633 \\
\hline 4 & Amlodipine & 2.244 & 1014299 & 1.1 & 4812 \\
\hline \multirow[t]{4}{*}{5} & Amlodipine & 2.458 & 1022159 & 1.0 & 3802 \\
\hline & Mean & & 1014008 & & \\
\hline & Std. Dev & & 4774.567 & & \\
\hline & $\%$ RSD & & 0.470861 & & \\
\hline
\end{tabular}

\begin{tabular}{|c|c|c|c|c|c|}
\hline $\begin{array}{l}\text { S. } \\
\text { No. }\end{array}$ & Peak name & Rt & $\begin{array}{c}\text { Area } \\
\left(\mu \mathrm{V}^{*} \text { sec }\right)\end{array}$ & $\begin{array}{l}\text { USP Plate } \\
\text { Count }\end{array}$ & $\begin{array}{c}\text { USP } \\
\text { Tailing }\end{array}$ \\
\hline 1 & Olmesartan & 3.294 & 1513391 & 1.2 & 4759 \\
\hline 2 & Olmesartan & 3.191 & 1513391 & 1.1 & 3695 \\
\hline 3 & Olmesartan & 3.076 & 1526673 & 1.1 & 4741 \\
\hline 4 & Olmesartan & 3.166 & 1560819 & 1.2 & 3793 \\
\hline \multirow[t]{4}{*}{5} & Olmesartan & 3.319 & 1560819 & 1.1 & 4741 \\
\hline & Mean & & 1535019 & & \\
\hline & Std. Dev. & & 24168.56 & & \\
\hline & $\%$ RSD & & 1.57448 & & \\
\hline
\end{tabular}

Table 7: Accuracy studies for Amlodipine

\begin{tabular}{cccccc}
\hline $\begin{array}{c}\% \\
\begin{array}{c}\text { Concentratio } \\
\mathbf{n}(\text { at } \\
\text { specification } \\
\text { Level) }\end{array}\end{array}$ & Area & $\begin{array}{c}\text { Amoun } \\
\text { t Added } \\
\text { (mg) }\end{array}$ & $\begin{array}{c}\text { Amoun } \\
\text { t Found } \\
\text { (mg) }\end{array}$ & $\begin{array}{c}\% \\
\text { recover } \\
\mathbf{y}\end{array}$ & $\begin{array}{c}\text { Mean } \\
\text { Recover } \\
\mathbf{y}\end{array}$ \\
\hline $80 \%$ & 605652 & & & & \\
$100 \%$ & 5 & 4 & 4.0 & $100.0 \%$ & \\
$120 \%$ & 1246314 & 5 & 4.94 & $98.0 \%$ & $99.9 \%$ \\
\hline
\end{tabular}

Table 8: Accuracy studies for Olmesartan

\begin{tabular}{|c|c|c|c|c|c|}
\hline $\begin{array}{c}\% \\
\text { Concentratio } \\
\mathbf{n}(\text { at } \\
\text { specification } \\
\text { Level) }\end{array}$ & Area & $\begin{array}{c}\text { Amoun } \\
\text { t Added } \\
\text { (mg) }\end{array}$ & $\begin{array}{l}\text { Amoun } \\
t \text { Found } \\
(\mathrm{mg})\end{array}$ & $\begin{array}{c}\% \\
\text { recover } \\
\mathbf{y}\end{array}$ & $\begin{array}{c}\text { Mean } \\
\text { Recover } \\
y\end{array}$ \\
\hline $80 \%$ & $\begin{array}{c}774787 . \\
7\end{array}$ & 16 & 15.9 & $99.37 \%$ & \multirow{3}{*}{$99.8 \%$} \\
\hline $100 \%$ & 1537580 & 20 & 19.9 & $99.5 \%$ & \\
\hline $120 \%$ & 2285575 & 24 & 24.1 & $100.4 \%$ & \\
\hline
\end{tabular}

\section{Accuracy results}

The accuracy of the method was determined by preparing solutions of different concentrations of AML and OLM that is $80 \%, 100 \%$ and $120 \%$ in which the amount of marketed formulation (AML and OLM $5 \mathrm{mg}$ and $20 \mathrm{mg}$ respectively) was kept constant and the amount of pure drug was varied that is $4 \mathrm{mg}, 5 \mathrm{mg}$ and $6 \mathrm{mg}$ for AML and $16 \mathrm{mg}, 20 \mathrm{mg}$ and $24 \mathrm{mg}$ for OLM i.e. $80 \%, 100 \%$ and $120 \%$ respectively. The solutions were prepared in triplicates and the accuracy; similarly was indicated by \% recovery in table 7 and 8 .

\section{Specificity}

$5 \mathrm{mg} / \mathrm{ml}$ of AML was spiked with 50\% (2.5 mg), 100\% (5 mg) and 150\% (7.5 mg) of excipient mix (Magnesium Stearate), Further $01 \mathrm{ml}$ is pippeted out from the all three samples and diluted to $100 \mathrm{ml}$ in three separate volumetric flask and analysed for \% recovery of AML. Similarly $20 \mathrm{mg} / \mathrm{ml}$ OLM sample were prepared and analysed.

\section{LOD and LOQ}

Detection limit and Quantitation limit of described method were observed as $0.653 \mathrm{mg} / \mathrm{ml}$ and $1.959 \mathrm{mg} / \mathrm{ml}$ for $\mathrm{AML}, 0.646 \mathrm{mg} / \mathrm{ml}$ and 1.638 $\mathrm{mg} / \mathrm{ml}$ for OLM.

\section{Robustness}

Robustness is a measure of capacity of a method to remain unaffected by small, but deliberate variations in the method conditions, and is indications of the reliability of the method. A method is robust, if it is unaffected by small changes in operating conditions. To determine the robustness of this method, the experimental conditions were deliberately altered at three different levels and retention time and chromatographic response were evaluated. One factor at a time was changed to study the effect. Variation of wavelength (235 and $239 \mathrm{~nm}$ ) and mobile phase flow rate by $0.1 \mathrm{ml} / \mathrm{min}(0.9$ and $1.1 \mathrm{ml} / \mathrm{min})$ had no significant effect on the retention time and chromatographic response of the $50 \mu \mathrm{g} / \mathrm{ml}$ solution, indicating that the method was robust.

Influence of small changes in chromatographic conditions such as change in flow rate $( \pm 0.1 \mathrm{ml} / \mathrm{min})$, Temperature $\left( \pm 2^{\circ} \mathrm{C}\right)$, Wavelength of detection $( \pm 2 \mathrm{~nm})$ $\&$ Acetonitrile content in mobile phase $( \pm 2 \%)$ studied to determine the robustness of the method are also in favour of (Table 10 and 11, \% RSD < 2\%) the developed RP-HPLC method for the analysis of Amlodipine.

The developed method was found to be precise as the $\%$ RSD values for intra-day and inter-day were found to be less than $2 \%$. Good recoveries ( $98.9 \%$ to $101.9 \%$ ) of the drug were obtained at each added concentration, indicating that the method was accurate.

Table 9: Results of specificity studies for Amlodipine and Olmesartan

\begin{tabular}{|c|c|c|c|c|c|c|}
\hline \multicolumn{7}{|c|}{ Specificity data for Amlodipine } \\
\hline $\begin{array}{c}\% \text { Concentration } \\
\text { (at specification Level) }\end{array}$ & Area & $\begin{array}{l}\text { Drug Added } \\
(\mathrm{mg})\end{array}$ & $\begin{array}{l}\text { Excipient Added } \\
\text { (mg) }\end{array}$ & $\begin{array}{l}\text { Amount Found } \\
(\mathrm{mg})\end{array}$ & $\%$ Recovery & $\begin{array}{c}\text { Mean } \\
\text { Recovery }\end{array}$ \\
\hline $50 \%$ & 444310 & 5 & 2.5 & 4.98 & $99.6 \%$ & \\
\hline $100 \%$ & 885413 & 5 & 5 & 4.97 & $99.7 \%$ & $99.6 \%$ \\
\hline $150 \%$ & 1319238 & 5 & 7.5 & 4.96 & $99.7 \%$ & \\
\hline \multicolumn{7}{|c|}{ Specificity data for Olmesartan } \\
\hline $\begin{array}{c}\% \text { Concentration } \\
\text { (at specification Level) }\end{array}$ & Area & $\begin{array}{l}\text { Drug Added } \\
(\mathrm{mg})\end{array}$ & $\begin{array}{l}\text { Excipient Added } \\
(\mathrm{mg})\end{array}$ & $\begin{array}{l}\text { Amount Found } \\
\text { (mg) }\end{array}$ & $\%$ Recovery & Mean Recovery \\
\hline $50 \%$ & 50577 & 20 & 10 & 19.97 & $99.4 \%$ & \\
\hline $100 \%$ & 104365 & 20 & 20 & 19.96 & $99.6 \%$ & $99.5 \%$ \\
\hline $150 \%$ & 156541 & 20 & 35 & 19.95 & $99.6 \%$ & \\
\hline
\end{tabular}


Table 10: Results of robustness for Amlodipine

\begin{tabular}{cc}
\hline Change in parameter & \% RSD \\
\hline Flow $(1.1 \mathrm{ml} / \mathrm{min})$ & 1.03 \\
Flow $(0.9 \mathrm{ml} / \mathrm{min})$ & 0.68 \\
Temperature $\left(27^{\circ} \mathrm{C}\right)$ & 0.42 \\
Temperature $\left(23^{\circ} \mathrm{C}\right)$ & 0.57 \\
Wavelength of Detection $(250 \mathrm{~nm})$ & 0.23 \\
Wavelength of detection $(266 \mathrm{~nm})$ & 0.12 \\
\hline
\end{tabular}

\begin{tabular}{cc} 
Table 11: Results of robustness for Olmesartan & \\
\hline Change in parameter & \% RSD \\
\hline Flow $(1.1 \mathrm{ml} / \mathrm{min})$ & 0.03 \\
Flow $(0.9 \mathrm{ml} / \mathrm{min})$ & 0.08 \\
Temperature $\left(27^{\circ} \mathrm{C}\right)$ & 0.19 \\
Temperature $\left(23^{\circ} \mathrm{C}\right)$ & 0.73 \\
Wavelength of Detection $(250 \mathrm{~nm})$ & 0.82 \\
Wavelength of detection $(266 \mathrm{~nm})$ & 0.46 \\
\hline
\end{tabular}

The method was also found to be specific indicated by the \% recoveries ranging from $99.8 \%$ to $99.9 \%$. The LOD and LOQ were found to be in sub-microgram level indicating the sensitivity of the method. The method was also found to be robust and rugged as indicated by the \%RSD values which are less than $2 \%$. The results of Assay show that the amount of drug was in good agreement with the label claim of the formulation as indicated by \% recovery $(99.6 \%$ for AML and $99.5 \%$ for OLM. The stress degradation studies showed that AML and OLM undergoes degradation in acidic and alkaline conditions whereas it is relatively stable when exposed to Amlodipine and Olmesartan were stable in photolytic, thermal and basic stress conditions. Summary of the results of stress degradation studies of AML and OLM are shown in the table 2 .

\section{ACKNOWLEDGEMENTS}

I, Dhiraj Kumar, thankful to Dr. P. Suresh, Associate Director, School of Pharmacy, GNITC Campus, Ibrahimpattnam, Hyderabad, for providing necessary facilities to carry out the research work.

\section{REFERENCES}

1. Wankhede SB, Wadkar SB, Raka KC, Chitlange SS Simultaneous Estimation of Amlodipine Besilate and Olmesartan Medoxomil in Pharmaceutical Dosage Form by UV spectrophotometer. International Journal of Pharmaceutical Sciences. 2009; 563-67.

2. Swarnkar V, Gill NK, Upadhyay Y, Sharma N, Rawal RK, Sarma GS. UV-Vis Spectrophotometric Method Development and Validation for simultaneous estimation of Amlodipine Besylate, Olmesartan Medoxomil and Hydrochlorothiazide. Inventi journal of pharmacy. 2013; 3:1037.
3. Mundra G, Dubey N, Chaturvedi SC, Jain DK. simultaneous estimation of Amlodipine Besylate, Olmesartan Medoxomil in combined dosage form using UV spectroscopy and RPHPLC method. International Journal of Biomedical and Pharmaceutical Sciences. 2011; 5(1):49-52.

4. Dhabale PN, Bhagade SR. Simultaneous UV Spectrophotometric Methods for Estimation of Amlodipine Besilate and Olmesartan Medoxomil in Tablet Dosage Form. Journal of Chemical and Pharmaceutical Research. 2011; 3(2):650-656.

5. Jyothirmai B, Tnvss S, Santosh T, Sundar BS. Development and validation of an RP- HPLC method for the determinaton of Olmesartan in human plasma. International journal of research in pharmacy and chemistry. 2014; 4(2): 457-466.

6. Srinivas A, Sneha Y. Stability indicating forced degradation RP-HPLC method development and validation of olmesartan medoxomil. International journal of pharmaceutical sciences and research. 2014; 5(7): 2841-2847.

7. Nalluri BN, Naik DV, Sunandana B, Sushmitha K Development and validation of RP-HPLC-PDA method for the simultaneous estimation of Hydrochlorothiazide, Amlodipine besylate and Olmesartan medoxomil in bulk and pharmaceutical dosage forms. Journal of Chemical and Pharmaceutical Research. 2013; 5(1):329-335.

8. Rao JR, Rajput MP, Yadav SS, Mulla TS, Bharekar VV. Simultaneous Quantitation of Olmesartan medoxomil, Amlodipine besylate and Hydrochlorothiazide in Pharmaceutical dosage form by using HPLC. International Journal of PharmTech Research. 2011; 3(1): 1435-1440.

9. Jain DK. Development and validation of RP-HPLC method for estimation of amlodipine besylate, olmesartan medoxomil and hydrochlorthiazide in tablet dosage form. International Journal of Research in Ayurveda and Pharmacy. 2014; 5(4):523-530 .

10. Chaitanya KK, Sankar DG, Israel DS. RP-HPLC Method development and validation of Amlodipine and Losartan in binary mixture. Journal of Global Trends in Pharmaceutical Sciences. 2013; 4(3): 1144-1152.

11. Thakker NM, Panchal HB, Rakholiya DR, Murugan R, Choudhari VP, Kuchekar BS. Development and validation of a stability indicating RP-HPLC method for simultaneous estimation of Olmesartan Medoxomil and Metoprolol Succinate in pharmaceutical dosage form. Pharm Methods. 2012; 3(2): 84-89.

12. Patil PS, More HN, Pishwikar SA. RP-HPLC Method for simultaneous estimation of Amlodipine besylate and Olmesartan medoxomil from tablet. International Journal of Pharmacy and Pharmaceutical Sciences. 2011; 3(3):146-149.

13. Chabukswara AR, Kuchekara BS, Jagdalea SC, Mehetrea DM, Morea AS, Lokhande PD. Development and validation of a RP-HPLC method for simultaneous estimation of Olmesartan Medoxomil and Amlodipine Besylate in tablet dosage form. Scholars Research Library Archives of Applied Science Research. 2010; 2 (4): 307-312.

14. https://www.webmd.com/drugs/2/drug 5891/amlodipine-oral/details

15. https://www.webmd.com/drugs/2/drug63172/olmesartan-oral/details

16. Draft ICH Guidelines on Validation of Analytical Procedures Definitions and terminology. Federal Register, vol 60. IFPMA, Switzerland, 1995, pp. 1126. 